Weed Science 2017 65:97-106

(C) Weed Science Society of America, 2016

\title{
Purple Nutsedge (Cyperus rotundus) Tuber Production and Viability Are Reduced by Imazapic
}

\author{
Theodore M. Webster, Timothy L. Grey, and Jason A. Ferrell*
}

Weeds exploit underutilized space, causing economic losses in cropping systems. Weed management tactics alter that underutilized space until the crop can mature and efficiently use that space. One tactic is to reduce the weed propagules (e.g., seeds and tubers) that persist quiescently in the soil, which includes minimizing production and addition of new propagules to the soil. Purple nutsedge is a problematic weed around the globe, persisting between growing seasons as tubers in the soil. Imazapic is a peanut herbicide often used in Georgia for control of purple nutsedge. The objective of the experiment was to evaluate the effect of various rates of imazapic on purple nutsedge tuber production. Single presprouted purple nutsedge tubers were transplanted into outdoor microplots and treated after 6 wk of growth with six rates of imazapic ( 5 to $140 \mathrm{~g}$ ai ha ${ }^{-1}$ ) POST. A nontreated control was included. All emerged shoots at the time of application were marked with plastic rings; this allowed for classification of tubers at exhumation as (1) tubers attached to shoots that were emerged at time of application, (2) tubers attached to shoots that emerged after application, and (3) tubers without an aerial shoot during the study. At $7 \mathrm{wk}$ after application, the tubers in the microplots were exhumed, classified, and quantified, and their ability to sprout was evaluated. In the nontreated control, there were 544 total tubers, with a log-logistic regression model describing the declining tuber population with increasing imazapic rate. The rate of imazapic that reduced total tuber population $50 \%\left(\mathrm{I}_{50}\right)$ was $36 \mathrm{~g} \mathrm{ha}^{-1}$. In the nontreated control, there were 161 tubers attached to shoots that emerged, as when compared with plots that received an imazapic application that had an $\mathrm{I}_{50}=60 \mathrm{~g} \mathrm{ha}^{-1}$. Viability of purple nutsedge tubers was $44 \%$ at $70 \mathrm{~g} \mathrm{ha}^{-1}$ imazapic, suggesting the action of the herbicide may have rendered the tubers nonviable after new shoots were produced. The final classification of tubers included those that did not have an aerial shoot during the study. These were tubers in which apical dominance suppressed shoot development or were likely the most recent tubers to develop. Of the three classes, the tubers without shoots were the most prevalent in the nontreated control, with 358 tubers and an $I_{50}=18 \mathrm{~g} \mathrm{ha}^{-1}$. Imazapic controls purple nutsedge foliage but also reduces the number of new tubers produced, and overall tuber viability and is a valuable tool in management of the long-term population density of this weed.

Nomenclature: Imazapic, purple nutsedge, Cyperus rotundus L., CYPRO.

Key words: AC 263,222, competition, peanut, perennial weed management.

Purple nutsedge is a nonnative weed of agricultural regions, particularly in the coastal plains of the southern United States, where the soil does not frequently freeze (Bryson and DeFelice 2009). A persistent weed of multiple crops throughout the world (Holm et al. 1977), purple nutsedge is among one of the most difficult to control in vegetable and agronomic crops due to its tolerance of many control practices, including many herbicides (Webster and Nichols 2012). A perennial member of the Cyperaceae family, purple

\footnotetext{
DOI: 10.1614/WS-D-16-00088.1

* First author: Supervisory Research Agronomist, Crop Protection and Management Research Unit, USDA-ARS, Tifton, GA 31794; second author: Professor, Department of Crop and Soil Sciences, University of Georgia, Tifton, GA 31794; third author: Professor, Department of Agronomy, University of Florida, Gainesville, FL 32611. Corresponding author's E-mail: tgrey@uga.edu
}

nutsedge primarily reproduces vegetatively via rhizomes and tubers, though it will flower and produce seed. Purple nutsedge tubers are oblong and irregularly shaped, often brown to black in color, and contain multiple axillary buds from which shoots sprout (Bryson and DeFelice 2009). Linked by rhizomes, tuber chains can extend radially from the initial mother plant, with a single tuber expanding to form a $22 \mathrm{~m}^{2}$ patch in 60 wk (Webster 2005b). During soil preparation prior to crop establishment, these tuber chains are often severed, likely releasing apical dominance and permitting these tubers to germinate. In the absence of competition, purple nutsedge will rapidly produce tubers; a single tuber and shoot developed a plant that produced 378 tubers after $107 \mathrm{~d}$ of growth (Webster 2005a). Over a 3 yr period in peanut, purple nutsedge tuber populations increased from 626 to 9,145 tubers $\mathrm{m}^{-3}$ in a nontreated control, 
while systems that included imazapic and other acetolactate synthase inhibitors reduced tuber populations to less than $10 \%$ of the initial population of the nontreated control (Warren and Coble 1999). Nutsedge tubers are known to be a major contaminant in harvested peanut due to their similar size and can even be identified in harvested peanut when complete control is maintained during the growing season (Johnson and Mullinix 2003). This is due to dormant tubers located in the soil from the previous year's infestations.

A branched-chain amino acid synthesis inhibitor (Group B2), imazapic is registered for weed control in peanut and widely used in Georgia and much of the southeast United States (Senseman 2007). Imazapic was applied to $56 \%$ of the U.S. peanut hectares in 2013 (National Agricultural Statistics Service 2013) as a POST application that provides residual weed control. Grichar et al. (2012) indicated that in spite of the high cost associated with imazapic, it provides the greatest net returns due to its ability to control a broad spectrum of weeds. Imazapic controls (>90\%) many common weeds in U.S. peanut production, including bristly starbur (Acanthospermum hispidum DC), citronmelon [Citrullus lanatus (Thunb.) Matsumura \& Nakai var. citroides (Bailey) Mansf.], coffee senna [Senna occidentalis (L.) Link], common cocklebur (Xanthium strumarium L.), morningglory species (Ipomoea spp.), prickly sida (Sida spinosa L.), sicklepod [Senna obtusifolia (L.) H. S. Irwin \& Barneby], and smallflower morningglory [Jacquemontia tamnifolia (L.) Griseb.] (Webster et al. 1997; Wilcut et al. 1996). However, one of its unique attributes is the ability to control purple and yellow nutsedge (Cyperus esculentus L.). When applied at the registered use rate (70 to $72 \mathrm{~g} \mathrm{ha}^{-1}$ ), imazapic controlled purple nutsedge $\geq 95 \%$ and yellow nutsedge $\geq 92 \%$ (Grichar and Nester 1997; Grichar et al. 2012; Webster et al. 1997). But variability in yellow and purple nutsedge control for this rate has also been reported, ranging from 39 to 93\% in peanut (Dotray and Keeling 1997; Wehtje and Brecke 2004). Imazapic has been shown to reduce carbon assimilation in yellow nutsedge plants by $50 \%$ after $2.1 \mathrm{~d}$, similar to halosulfuron but more rapid than glyphosate or MSMA (Ferrell et al. 2004).

Effective weed control programs minimize impact of the weed in the current crop year. However, effective weed management strategies should extend beyond a single season and target reducing the number of propagules added annually that persist in the soil (Gallandt 2006; Mortensen et al. 2000), especially in peanut (Johnson and Mullinix 2003). Imazapic may have the potential to reduce tuber production and cause a decline in purple nutsedge tuber density in the soil propagule bank. However, the effect of imazapic on purple nutsedge tuber production when applied to mature plants is unknown. Therefore, the objective of this study was to quantify the effects of imazapic on tuber production and further evaluate the effects on tubers: (1) attached to shoots emerged at the time of application, (2) attached to shoots that emerged after imazapic application, and (3) without aerial shoots during the study.

\section{Materials and Methods}

Purple nutsedge tubers were collected in 2013 and 2014 from a naturalized population in Tift County, GA, using a field cultivator; tuber chains become entangled on the tines of the cultivator and are removed from the machinery after each pass through the field. In 2015 purple nutsedge tubers were collected at the Plant Science Research and Education Unit in Citra, FL, using the previously described procedures. Tubers were then hand separated and classified by size; tubers that were approximately $1.2 \mathrm{~cm}$ long and $0.75 \mathrm{~cm}$ wide and had a fresh biomass of approximately $1.1 \mathrm{~g}$ were used to ensure a uniform tuber size for the study (Wallace et al. 2013). For each experiment, tubers were then planted in pots with steam-sterilized soil and grown in the greenhouse for approximately $3 \mathrm{wk}$, after which they were transplanted into the experimental units, following the methods of Webster and Grey (2014). Purple nutsedge tubers with a single shoot were transplanted (one per treatment) into outdoor microplots on April 15, 2013, April 3, 2014, and April 8, 2015, at the U.S. Department of Agriculture-Agricultural Research Service Crop Protection and Management Research Unit in Tifton, GA $\left(31.48^{\circ} \mathrm{N}, 83.53^{\circ} \mathrm{W}\right)$. Microplots consisted of plastic containers $(76 \mathrm{~cm}$ diameter, countersunk into the ground to a depth of $76 \mathrm{~cm}$ ) filled with steam-sterilized Tifton loamy sand (fine-loamy, kaolinitic, thermic, plinthic, Kandiudult) with $\mathrm{pH} 6.5$ and organic matter $0.8 \%$. Soil moisture in microplots was maintained by irrigation as needed via a microjet emitter system. After 6 wk of purple nutsedge growth, imazapic (Cadre 2L; BASF, Research Triangle Park, NC 27709) was applied POST using a $\mathrm{CO}_{2}$-pressurized backpack sprayer equipped with flat-fan nozzles calibrated to deliver $140 \mathrm{~L} \mathrm{ha}^{-1}$ at $275 \mathrm{kPa}$. A nonionic surfactant was included at $0.25 \%$ $(\mathrm{v} / \mathrm{v})$ for each treatment. Six rates of imazapic $(5,9,18$, 35,70 , and $140 \mathrm{~g}$ ai $\mathrm{ha}^{-1}$ ) were selected on a

98 - Weed Science 65, January-February 2017 
logarithmic dose using a common multiplier of 2 (Seefeldt et al. 1995). A nontreated control was also included. Treatments were arranged as a randomized complete block design, blocked by the number of emerged purple nutsedge shoots at the time of application; there were five replications of each treatment.

Visual evaluation of foliar chlorosis/necrosis occurred at $7 \mathrm{wk}$ after treatment (WAT), using a scale of 0 (no shoot injury) to 100 (complete necrosis). At 7 WAT, digital images of 12.2 megapixels were taken directly over each microplot; images were then analyzed for level of green color using ImageJ software (W. Rasbaud, National Institutes of Health, http://imagej.nih.govij). All of the area outside each round microplot had a black vignette placed around it to allow for accurate estimation of the percent green area in each treatment, which was then expressed as a percentage of the value in the nontreated control.

Individual shoots emerged at the time of imazapic application were marked with 0.3 to $0.5 \mathrm{~cm}$ length plastic rings that were slid over leaf blades to the base of each plant to the soil surface (Webster 2005a). The parent tuber was marked at emergence with a plastic ring, and then subsequent shoots were marked in the same fashion prior to imazapic application. Care was taken to ensure that the plastic rings remained in place during the entire growing season. This allowed for the classification of tubers at exhumation as: (1) tubers attached to shoots that were emerged at time of application, (2) tubers attached to shoots that emerged after application, and (3) tubers without an aerial shoot during the study. At 7 WAT, all purple nutsedge plant material from each microplot was exhumed, tubers were sorted according to the previously described classification scheme, and all plant material was then quantified.

Purple nutsedge tubers were then evaluated for viability by placing them between moistened paper towels that were placed in sealable plastic bags that were then placed in plastic bins under greenhouse benches. The average greenhouse day/night temperatures were $32 / 24$ C. Tuber viability was evaluated three times each week over a $90 \mathrm{~d}$ period; tubers were scored viable once a $3 \mathrm{~mm}$ shoot developed. Tubers that did not sprout during this time and exhibited signs of decay were considered nonviable.

Data were subjected to a mixed-model ANOVA (SAS Institute 2012), with herbicide rate as a fixed factor, while years and the interaction were random factors. The relationships between nutsedge responses and imazapic rate were fit to a log-logistic regression model,

$$
y=\left(\frac{d}{1+\exp \left\{b\left[\log (x)-\log \left(\mathrm{I}_{50}\right)\right]\right\}}\right)
$$

where $y$ is purple nutsedge response (i.e., tuber numbers, tuber and shoot biomass, and estimated nutsedge control), $d$ is the upper limit of the regression, $x$ is the rate of imazapic, $\mathrm{I}_{50}$ is the rate of imazapic that provides median purple nutsedge response, and $b$ is the slope of the regression at $\mathrm{I}_{50}$ (Ritz et al., 2013; Seefeldt et al., 1995). Differences among parameters between regression models were evaluated using a $t$-test (Glantz and Slinker 2001). An

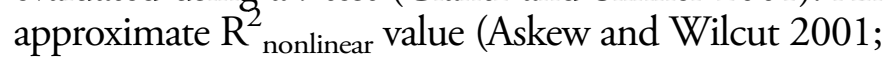
Jasieniuk et al. 1999) was calculated as:

$$
\mathrm{R}_{\text {nonlinear }}^{2}=1-\left(\frac{\text { Residual sum of squares }}{\text { Corrected total sum of squares }}\right)
$$

\section{Results and Discussion}

Foliage. Visual ratings of purple nutsedge foliar chlorosis at 7 WAT were regressed on imazapic rate and fit $\left(\mathrm{R}^{2}\right.$ nonlinear $\left.\geq 0.77, \mathrm{P}<0.0001\right)$ to a log-logistic regression model (Figure 1). The rate of imazapic needed to cause a $50 \%$ response (parameter $\mathrm{I}_{50}$ ) was estimated at $35 \mathrm{~g} \mathrm{ha}^{-1}$ (Table 1), while the registered use rate in peanut $\left(70 \mathrm{~g} \mathrm{ha}^{-1}\right)$ caused $66 \%$ foliar chlorosis (Figure 1). Previous studies have documented $>95 \%$ control of purple nutsedge late in the season ( $\geq 94 \mathrm{~d}$ after treatment), but this occurred in the

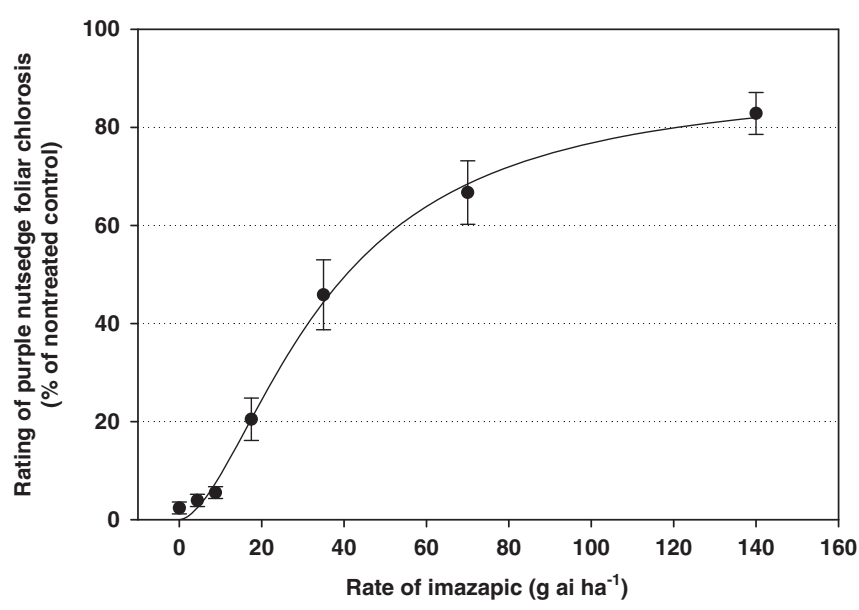

Figure 1. The relationship between rate of imazapic and a visual rating of foliar chlorosis at 7 weeks after imazapic treatment. Each treatment mean is combined over replications and years, with the vertical lines around each treatment mean representing the standard errors. The parameters of the log-logistic regression equation are found in Table 1. 
Table 1. Parameter estimates and their standard errors from the log-logistic regression models ${ }^{\mathrm{a}}$ relating to purple nutsedge foliar response to rate of imazapic in Figures 1, 2, and 3.

\begin{tabular}{lccccrrrr}
\hline Nutsedge shoot response & $\mathrm{I}_{50}{ }^{\mathrm{b}}$ & $\mathrm{SE}$ & $b^{\mathrm{c}}$ & se & $d^{\mathrm{d}}$ & $\mathrm{SE}$ & $\mathrm{R}_{\text {nonlinear }}$ & $\mathrm{P}_{\text {-value }}$ \\
\hline Foliar chlorosis (7 WAT) & 35 & 6.2 & -3.9 & 0.8 & 90 & 8.9 & 0.77 & $<0.0001$ \\
Total biomass of shoots & 23 & 5.0 & 2.6 & 0.5 & 133 & 9.7 & 0.52 & $<0.0001$ \\
Foliar area (\% of control) & 22 & 3.0 & 3.2 & 0.5 & 94 & 4.7 & 0.71 & $<0.0001$ \\
\hline
\end{tabular}

${ }^{\text {a }}$ Model: $y=\left(\frac{d}{1+\exp \left\{b\left[\log (x)-\log \left(\mathrm{I}_{50}\right)\right]\right\}}\right), \mathrm{R}_{\text {nonlinear }}^{2}=1-\left(\frac{\text { Residual sum of squares }}{\text { Corrected total sum of squares }}\right)$.

${ }^{\mathrm{b}}$ The $\mathrm{I}_{50}$ parameter is the rate of imazapic ( $\mathrm{g}$ ai ha ${ }^{-1}$, as in Table 2) that imparts a $50 \%$ reduction in the measured nutsedge shoot response.

${ }^{c}$ The $b$ parameter is the slope of the regression around the $\mathrm{I}_{50}$.

${ }^{\mathrm{d}}$ Parameter $d$ is the maximum nutsedge shoot response of the regression.

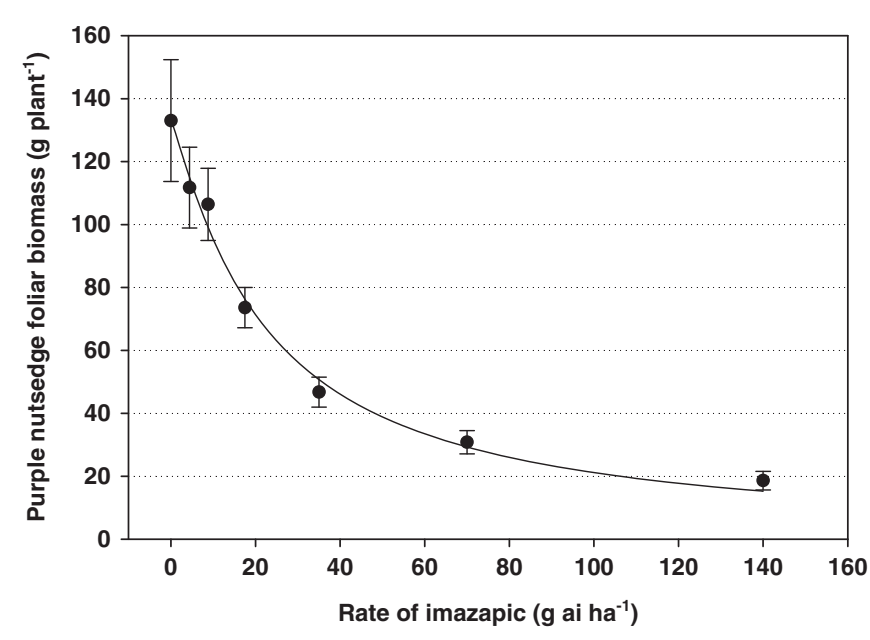

Figure 2. The log-logistic relationship between dry shoot biomass at the conclusion of the season and rate of imazapic. Each treatment mean is combined over replications and years, with the vertical lines around each treatment mean representing the standard errors. The parameters of the regression equation are in Table 1.

presence of a competitive peanut crop (Grichar and Nester 1997). Purple nutsedge is intolerant of plant competition that limits light interception by the weed and will typically not maintain foliar growth under these conditions (Stoller and Sweet 1987).

Purple nutsedge shoot biomass was reduced by increasing rates of imazapic (Figure 2) and fit to a log-logistic regression model $\left(\mathrm{R}^{2}\right.$ nonlinear $=0.71$, $\mathrm{P}<0.0001)$. For each microplot planted with an initial sprouted tuber, total shoot biomass ranged from 19 to $133 \mathrm{~g} \mathrm{plant}^{-1}$ at the highest rate of imazapic and the nontreated control, respectively. The $\mathrm{I}_{50}$ for shoot biomass was $23 \mathrm{~g} \mathrm{ha}^{-1}$ imazapic, which was not different $(P=0.13)$ from the $I_{50}$ for foliar chlorosis rating. At imazapic rates of $70 \mathrm{~g} \mathrm{ha}^{-1}$ and $140 \mathrm{~g} \mathrm{ha}^{-1}$, shoot biomass was reduced by 70 and $82 \%$, respectively, compared with the nontreated control. Richburg et al. (1994) determined that $71 \mathrm{~g} \mathrm{ha}^{-1}$ imazapic applied to 15 -d-old purple nutsedge plants reduced shoot dry biomass by $>89 \%$

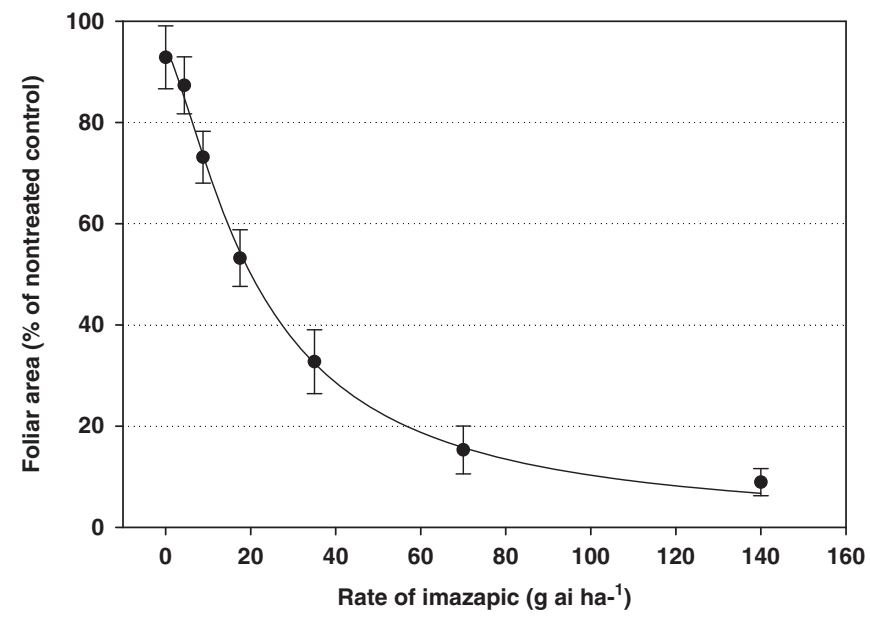

Figure 3. The relationship between rate of imazapic and foliar area (measured by the number of green pixels) expressed as a percent of the nontreated control at 7 weeks after imazapic treatment. Each treatment mean is combined over replications and years, with the vertical lines around each treatment mean representing the standard errors. The parameters of the log-logistic regression equation are in Table 1.

at $28 \mathrm{~d}$ after treatment and shoot regrowth by $>93 \%$ after an additional $14 \mathrm{~d}$.

A digital assessment of green foliar area was regressed on imazapic rate and fit $\left(\mathrm{R}^{2}\right.$ nonlinear $=0.71$, $\mathrm{P}<0.0001$ ) to a log-logistic regression (Figure 3). This objective measurement nondestructively assessed both the amount of chlorosis and the overall reduction in shoot growth and ranged from 9 to $97 \%$ foliar area relative to the nontreated control at the highest and lowest rates of imazapic, respectively. The estimated $\mathrm{I}_{50}$ was $22 \mathrm{~g} \mathrm{ha}^{-1}$ of imazapic (Table 1), but this value was not different $(P=0.063)$ from the $I_{50}$ for the visual ratings of chlorosis, though the standard error of the digital assessment was half that of the visual ratings. Imazapic at 70 and $140 \mathrm{~g} \mathrm{ha}^{-1}$ reduced purple nutsedge foliar area to 15 and $9 \%$ of the nontreated control, respectively (Figure 3). The ratio of registered use rate to the $50 \%$ response $\left(1 \times: \mathrm{I}_{50}\right)$ for green foliar area was 3.2. A similar-methodology applied to purple

100 - Weed Science 65, January-February 2017 
nutsedge response to halosulfuron determined that the $1 \times: \mathrm{I}_{50}$ was 6.5 , suggesting a greater foliar response from purple nutsedge to halosulfuron than observed with imazapic at the registered rates (Webster and Grey 2014). Purple nutsedge has been shown to decrease soybean yields by up to $12 \%$ with densities of 25 plant $\mathrm{m}^{-2}$, and can reduce yields up to $48 \%$ at 200 plants $\mathrm{m}^{-2}$ (Das et al. 2014). For that study, the authors determined that the economic threshold for herbicide application for purple nutsedge control was 19 to 22 purple nutsedge plants $\mathrm{m}^{-2}$. A review of the literature indicated that this type of research has not been conducted for peanut.

Tubers. In the nontreated control, there was an average of 544 total tubers (parameter $d$ ) produced from a single tuber during the 13 wk study (Table 2). This number is comparable to that previously reported for purple nutsedge (530 tubers) using a similar methodology (Webster and Grey 2014). The relationship between total purple nutsedge tuber population and rate of imazapic was described $\left(\mathrm{R}_{\text {nonlinear }}^{2}=0.47, \mathrm{P}<0.0001\right)$ by a log-logistic regression model (Figure $4 \mathrm{~A}$ ). The $\mathrm{I}_{50}$ for total tuber population was $36 \mathrm{~g} \mathrm{ha}^{-1}$ imazapic (Table 2), similar to $\mathrm{I}_{50}$ values for foliar chlorosis $(\mathrm{P}=0.92)$ and green area $(\mathrm{P}=0.0757)$. At the registered use rate in peanut $\left(70 \mathrm{~g} \mathrm{ha}^{-1}\right)$, there was a $75 \%$ reduction in total tuber population, while increasing imazapic rate to $140 \mathrm{~g} \mathrm{ha}^{-1}$ reduced tuber population density by $85 \%$ relative to the nontreated control. Imazapic has been successfully applied with little to no reported injury concerns or reduction in grade and yield of runner-type peanut for more than $20 \mathrm{yr}$ (Dotray et al. 2001; Faircloth and Prostko 2010; Grey et al. 2003; Richburg et al. 1995; Teuton et al. 2004). Peanut producers should follow the recommended $70 \mathrm{~g} \mathrm{ha}^{-1}$ of imazapic and not reduce the rate to ensure purple nutsedge control that will reduce tuber production and eliminate some foreign material issues during the processing procedure (Whitaker et al. 2008).

The complex nature of vegetative reproduction provides opportunities for herbicides to target tubers at different stages of growth. To evaluate the response of purple nutsedge tubers in different growth stages to imazapic, tubers were separated based on the absence or presence of a foliar shoot that emerged before or after the application of imazapic. In the nontreated control, there were 37 tubers that were attached to foliar shoots at the time of imazapic application; there was no response $(P=0.9575)$ in tuber numbers in this class to imazapic rates (Figure $4 \mathrm{~B}$ ). These were established tubers, and there is no reason to think there would be any differences in tuber numbers in the short duration of the study. Regression parameter $d$, an estimate of tuber population in the nontreated control, indicated there were 161 tubers attached to shoots that emerged after imazapic application (i.e., late-emerging tubers) (Figure 4C) and 358 tubers that did not have aerial shoots (i.e., shootless tubers) (Figure 4D). Relative to tubers attached to shoots that had emerged before imazapic application, both the late-emerging and shootless tuber classifications likely represent

Table 2. Parameter estimates and their standard errors of the log-logistic regression models ${ }^{\mathrm{a}}$ that relate purple nutsedge tuber response to rate of imazapic in Figures 4, 5, and 6.

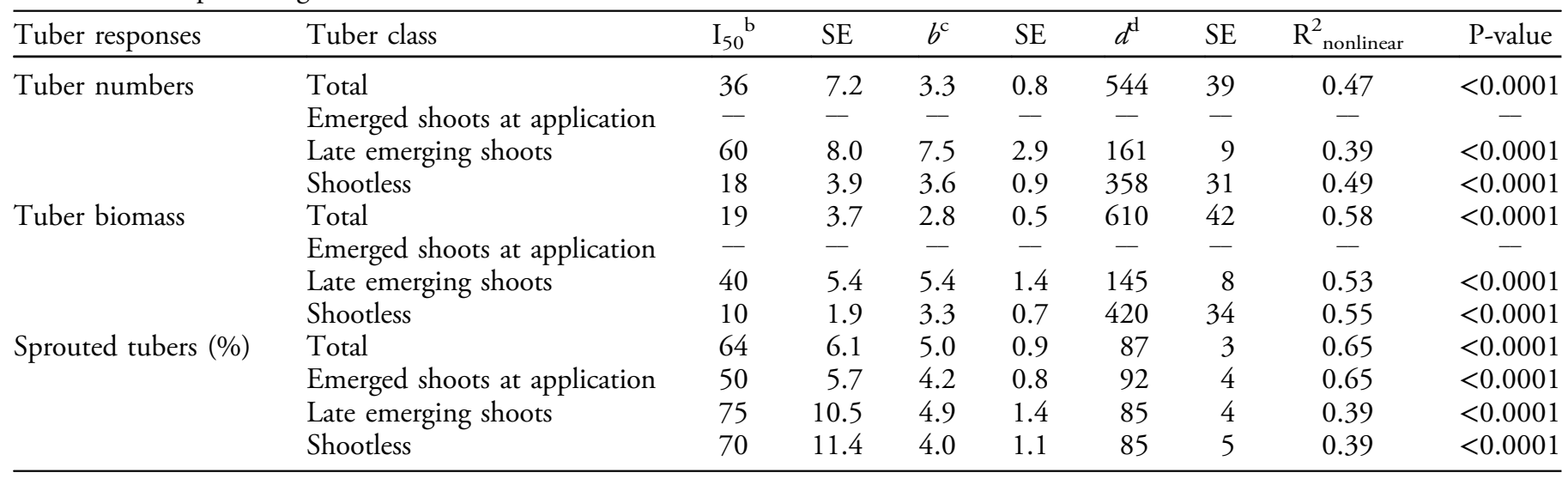

${ }^{\mathrm{a}}$ Model: $y=\left(\frac{d}{1+\exp \left\{b\left[\log (x)-\log \left(\mathrm{I}_{50}\right)\right]\right\}}\right), \mathrm{R}_{\text {nonlinear }}^{2}=1-\left(\frac{\text { Residual sum of squares }}{\text { Corrected total sum of squares }}\right)$

${ }^{\mathrm{b}}$ The $\mathrm{I}_{50}$ parameter is the rate of imazapic $\left(\mathrm{g}\right.$ ai ha $\left.{ }^{-1}\right)$ that imparts a $50 \%$ reduction in the measured nutsedge shoot response.

${ }^{c}$ The $b$ parameter is the slope of the regression around the $\mathrm{I}_{50}$.

${ }^{\mathrm{d}}$ Parameter $d$ is the maximum nutsedge shoot response of the regression. There was no change in number or biomass of tubers with emerged shoots when imazapic was applied. 

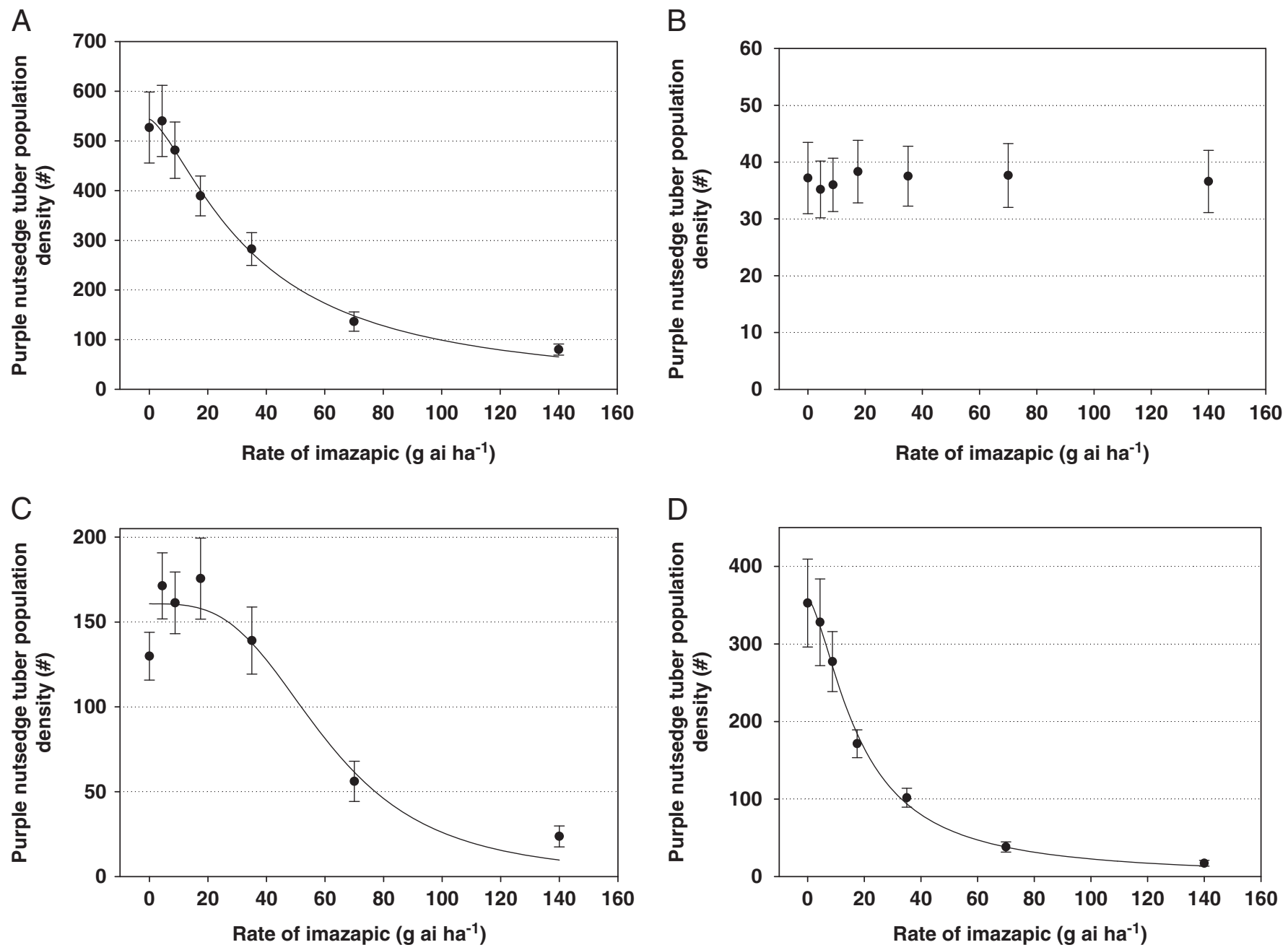

Figure 4. The log-logistic relationship between imazapic rate and total tuber number (A), number of tubers with emerged aerial shoots at the time of imazapic application (B), number of tubers with aerial shoots that emerged following imazapic application (C), and number of tubers without aerial shoots (D). Each treatment mean is combined over replications and years, with the vertical lines around each treatment mean representing the standard errors. The parameters of the regression equation are in Table 2.

younger tubers that were nutrient sinks and potential destinations for imazapic. Population densities for both the late-emerging and shootless tuber classes were fit to log-logistic regression models $\left(\mathrm{R}^{2}\right.$ nonlinear $=0.39$ to $0.49, \mathrm{P}<0.0001)$. Late-emerging tuber numbers had an $\mathrm{I}_{50}$ of $60 \mathrm{~g} \mathrm{ha}^{-1}$ imazapic, which was three times greater $(\mathrm{P}<0.0001)$ than that for the shootless tuber numbers $\left(\mathrm{I}_{50}=18 \mathrm{~g} \mathrm{ha}^{-1}\right)$. Differences in tuber population density response to imazapic between late-emerging and shootless tubers were consistent with previous findings with halosulfuron (Webster and Grey 2014).

Total tuber fresh biomass $\left(\mathrm{I}_{50}=19 \mathrm{~g} \mathrm{ha}^{-1}\right)$ was more sensitive $(\mathrm{P}=0.0429)$ to imazapic (Figure $5 \mathrm{~A}$ ) than was total tuber population density $\left(\mathrm{I}_{50}=36 \mathrm{~g}\right.$ $\mathrm{ha}^{-1}$ ) (Figure 4A), as indicated by their slopes $(3.3>2.8)$ (Table 2). Imazapic rate did not affect $(\mathrm{P}>0.63)$ biomass of tubers attached to shoots emerged at application, because they were already established at the time of application, and imazapic prevented development of new tubers (Figure 5B). Biomass of total tubers, late-emerging tubers, and shootless tubers was regressed on imazapic rate and fit to log-logistic models $\left(\mathrm{R}^{2}\right.$ nonlinear $=0.53$ to 0.58 , $\mathrm{P}<0.0001$ ) (Figure $5 \mathrm{~A}, \mathrm{C}, \mathrm{D})$. The $\mathrm{I}_{50}$ for total tuber biomass $\left(19 \mathrm{~g} \mathrm{ha}^{-1}\right.$ imazapic) was greater $(\mathrm{P}=0.026)$ than that of the biomass of shootless tubers $\left(\mathrm{I}_{50}=10 \mathrm{~g} \mathrm{ha}^{-1}\right)$ but less $(\mathrm{P}=0.0016)$ than that of the biomass of late-emerging tubers $\left(\mathrm{I}_{50}=40 \mathrm{~g} \mathrm{ha}^{-1}\right)$. In the nontreated control, greater tuber biomass occurred in the shootless tuber class $\left(420 \mathrm{~g} \mathrm{plant}^{-1}\right.$ or $69 \%$ ), with late-emerging tubers representing $24 \%$ $\left(145 \mathrm{~g} \mathrm{plant}^{-1}\right)$, and tubers attached to shoots emerged at application contributed $7 \%\left(45 \mathrm{~g} \mathrm{plant}^{-1}\right)$.

The sprouting of tubers over a $60 \mathrm{~d}$ period in the laboratory following harvest was used to estimate the

102 - Weed Science 65, January-February 2017 
A

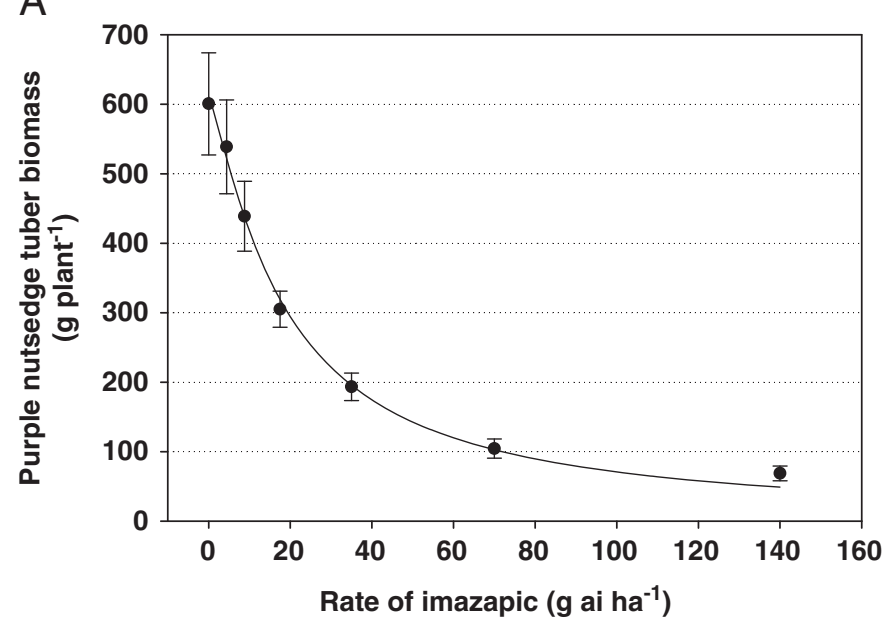

C

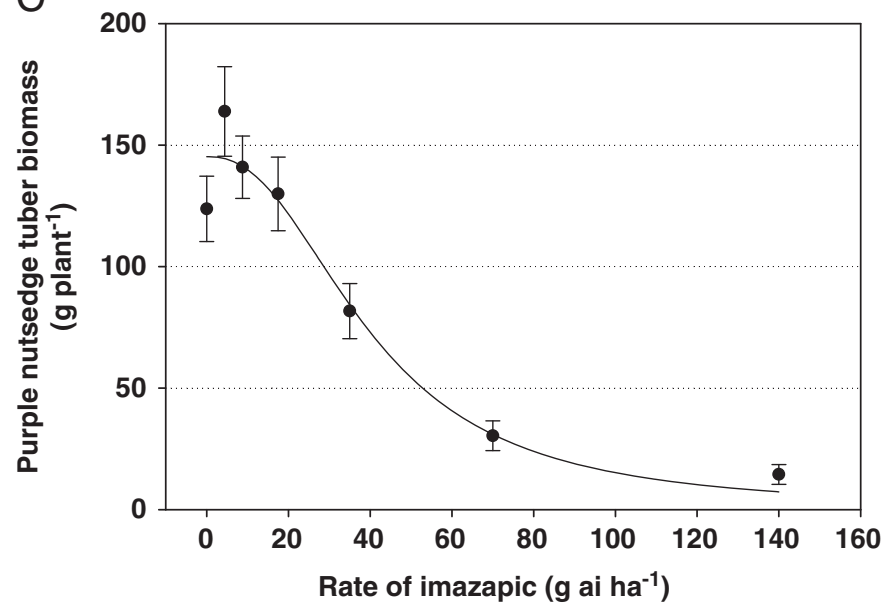

B

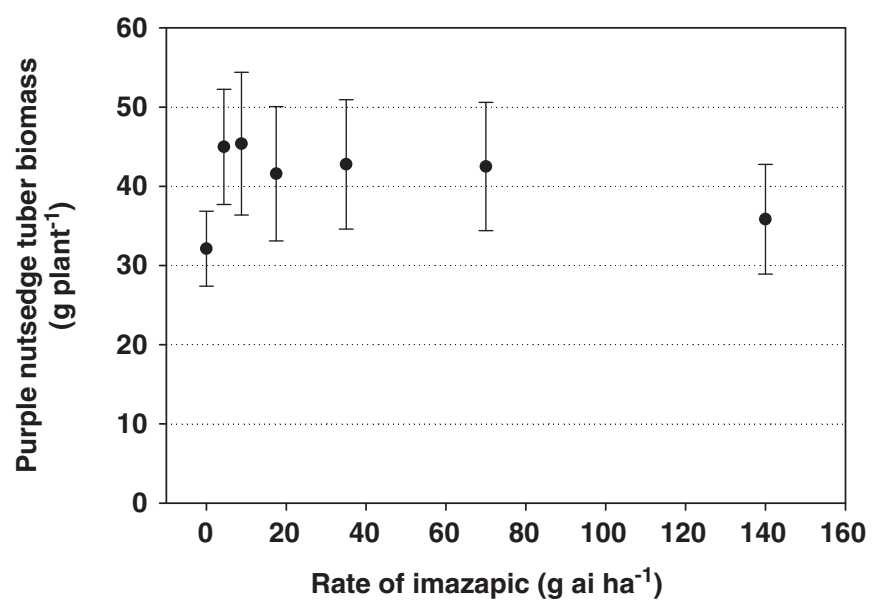

$\mathrm{D}$

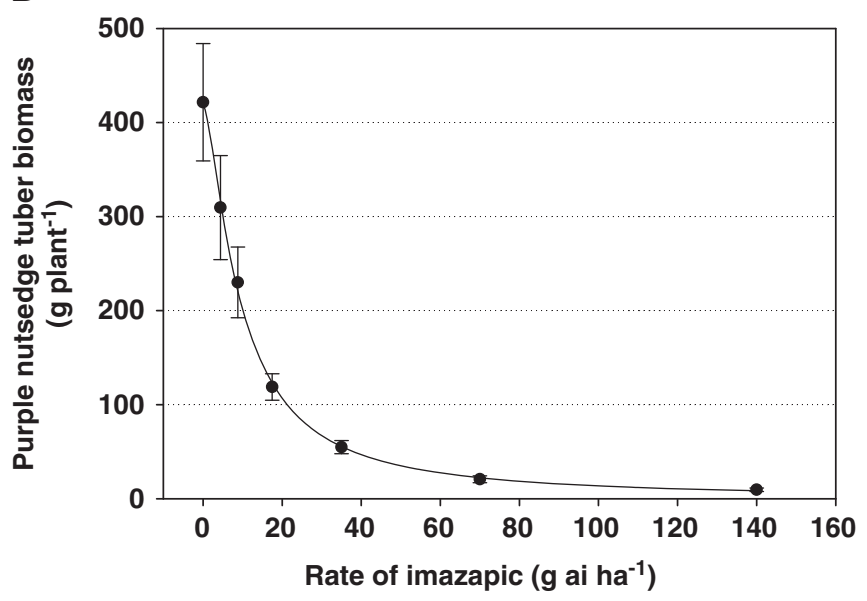

Figure 5. The log-logistic relationship between imazapic rate and total tuber biomass (A), biomass of tubers with aerial shoots at the time of imazapic application (B), biomass of tubers with aerial shoots that emerged following imazapic application (C), and biomass of tubers without aerial shoots (D). Each treatment mean is combined over replications and years, with the vertical lines around each treatment mean representing the standard errors. The parameters of the regression equation are in Table 2.

effect of imazapic on the number of viable tubers (Webster and Grey 2014). Assessment of the maximum total tuber sprouting (parameter $d$ ) ranged from 85 to $92 \%$ across the tuber classes (Table 2). For each tuber class, sprouting ability was regressed on rates of imazapic and fit to log-logistic regression models $\left(\mathrm{R}^{2}\right.$ nonlinear $=0.39$ to $0.65, \mathrm{P}<0.0001$; Figure $6 \mathrm{~A}-$ D). Purple nutsedge forms chains of tubers, and translocation of imazapic from the foliage to roots and tubers likely occurred. Translocation has been reported for imazapic in johnsongrass [Sorghum halepense (L.) Pers.] and sicklepod (Newsom et al. 1993). The $\mathrm{I}_{50}$ for viability ranged from 50 to $75 \mathrm{~g} \mathrm{ha}^{-1}$ imazapic, with only shoots emerged at the time of application $\left(\mathrm{I}_{50}=0.50\right)$ having lower values $(\mathrm{P}=0.046)$ than tubers attached to late-emerging shoots $\left(\mathrm{I}_{50}=75 \mathrm{~g}\right.$ $\left.\mathrm{ha}^{-1}\right)$; for all other comparisons, there were no detectable differences $(\mathrm{P}>0.1292)$. This occurred due to the sensitivity of purple nutsedge to imazapic. While imazapic reduced purple nutsedge tuber viability, the effect was not as strong as previously observed with halosulfuron. With imazapic, the $1 \times: \mathrm{I}_{50}$ ratio for viability among the tuber classes ranged from 0.93 to 1.40 , while this ratio with halosulfuron at the vegetable use rate $\left(52 \mathrm{~g} \mathrm{ha}^{-1}\right)$ ranged from 2.4 for tubers attached to late-emerging shoots to 6.5 for tubers attached to shoots emerged at the time of application (Webster and Grey 2014).

One of the challenges of purple nutsedge management is the extensive subterranean component of the plant; the visible foliar shoots represent only part of the overall plant biomass. There was a positive linear correlation $(r=0.86)$ between the biomass of all tubers and biomass of emerged shoots; for every $1 \mathrm{~g}$ of emerged shoots there were $4.5 \mathrm{~g}$ of tuber biomass in the soil (Figure 7), similar to what

Webster at al.: Imazapic effects on purple nutsedge • 103 

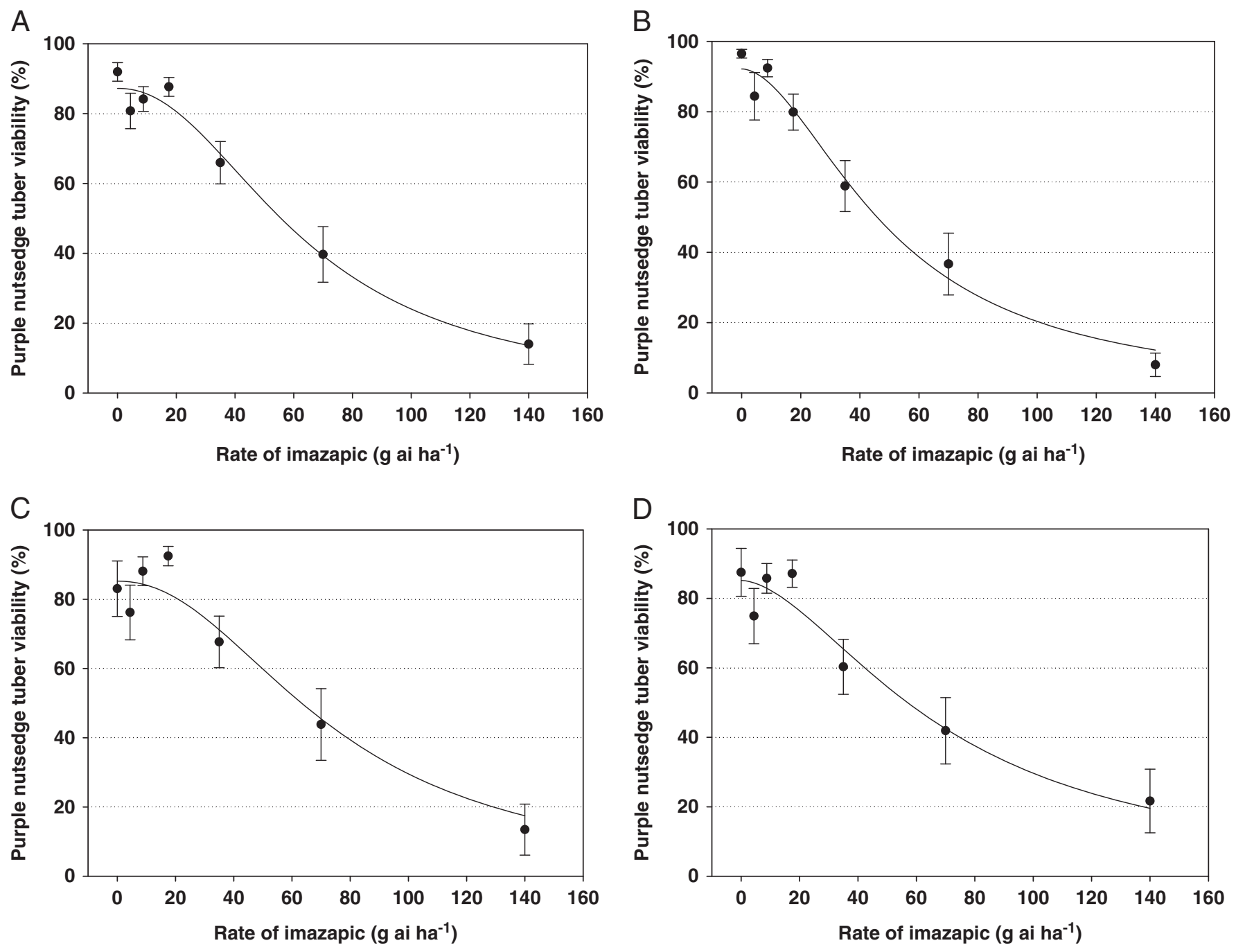

Figure 6. The log-logistic relationship between imazapic rate and viability of all tubers (A), viability of marked tubers (B), viability of tubers with aerial shoots that emerged following imazapic application (C), and viability of tubers without aerial shoots (D). Each treatment mean is combined over replications and years, with the vertical lines around each treatment mean representing the standard errors. The parameters of the regression equation are in Table 2.

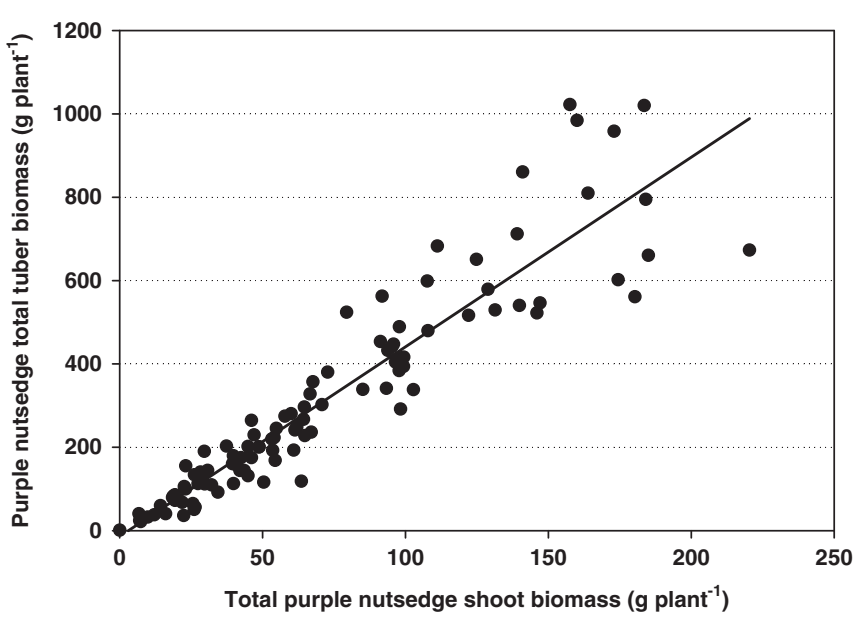

Figure 7. The correlation between the biomass of tubers and the biomass of emerged shoots for all treatments. $y=4.5 x-13.5$, $r=0.86(\mathrm{P} \leq 0.001)$. was previously reported (Webster and Grey 2014). In addition, total tuber biomass and total shoot biomass had similar $(\mathrm{P}=0.0429) \mathrm{I}_{50}$ values $\left(\mathrm{I}_{50}=19\right.$ and $23 \mathrm{~g} \mathrm{ha}^{-1}$ imazapic, respectively), a phenomenon that was previously observed with purple nutsedge shoot and tuber response to glyphosate and halosulfuron (Webster and Grey 2014; Webster et al. 2008). Therefore, the foliage of purple nutsedge will provide an accurate estimate of the level of subterranean population (4.5-fold difference), and the impact of the imazapic on foliage will similarly impact the tubers.

Conclusions. Imazapic has been shown to be an important component for reducing the long-term population density of purple nutsedge (Warren and 
Coble 1999). We have shown that imazapic reduces growth of purple nutsedge foliage and tuber population density, biomass, and viability. In the nontreated control, there were 161 tubers that were attached to shoots that emerged following imazapic application, while the registered imazapic rate reduced shoot numbers $65 \%$. Without a nontreated control, however, this new shoot emergence may have given the initial impression that the treatment was ineffective, as shoot numbers more than doubled following application of $70 \mathrm{~g} \mathrm{ha}^{-1}$ imazapic. In addition, imazapic reduced the viability of these tubers to $36 \%$ at $70 \mathrm{~g} \mathrm{ha}^{-1}$, suggesting the action of the herbicide may have rendered the tubers nonviable after new shoots were produced. Tubers without an aerial shoot during the study were likely those in which shoot development was either suppressed by apical dominance based on their relative position in the tuber chain or were the most recent tubers to develop and lacked sufficient time to develop shoots. Of the three classes, the shootless tubers were the most prevalent in the nontreated control, with 358 tubers. Overall, $70 \mathrm{~g} \mathrm{ha}^{-1}$ imazapic reduced purple nutsedge shootless tuber production by $89 \%$, with only $42 \%$ viability of the tubers produced. Imazapic used in rotation with glyphosate (Webster et al. 2008) or halosulfuron (Webster and Grey 2014) will minimize tuber reproduction, an important component used to reduce the long-term population density of purple nutsedge and similar weeds that are difficult to manage.

\section{Acknowledgments}

The National Peanut Board, the University of Georgia, and USDA-ARS funded this work. Technical assistance and overall coordination of this study was provided by Thomas Sklany. Sidney Cromer collected and analyzed the digital images. Assistants involved in harvesting and processing of this study were Danielle Simmons, Haydon Davis, Brian Blanchett, and Fritz Turpin.

\section{Literature Cited}

Askew SD, Wilcut JW (2001) Tropic croton interference in cotton. Weed Sci 49:184-189

Bryson CT, DeFelice MS, eds (2009) Weeds of the South. Athens: University of Georgia Press. 468 pp

Das TK, Paul AK, Yaduraju NT (2014) Density-effect and exonomic threshold of purple nutsedge in soybean. J Pest Sci 87:211-220

Dotray PA, Baughman TA, Keeling JW, Grichar WJ, Lemon RG (2001) Effect of imazapic application timing on Texas peanut. Weed Technol 15:26-29

Dotray PA, Keeling JW (1997) Purple nutsedge control in peanut as affected by imazameth and imazethapyr application timing. Peanut Sci 24:113-116
Faircloth WH, Prostko EP (2010) Effect of imazapic and 2,4-DB on peanut yield, grade, and seed germination. Peanut Sci 37:78-82

Ferrell JA, Earl HJ, Vencill WK (2004) Duration of yellow nutsedge competitiveness after herbicide treatment. Weed Sci 52:24-27

Gallandt ER (2006) How can we target the weed seedbank? Weed Sci 54:588-596

Glantz SA, Slinker BK (2001) Primer of Applied Regression and Analysis of Variance. 2nd edn. New York: McGraw-Hill. Pp. 25-28

Grey TL, Bridges DC, Prostko EP, Eastin EF, Johnson WC 3rd, Vencill WK, Brecke BJ, MacDonald GE, Ducar JA, Everest JW, Wehtje GR, Wilcut JW (2003) Residual weed control with imazapic, diclosulam, and flumioxazin in Southeastern peanut. Peanut Sci 30:27-34

Grichar WJ, Jordan DL, Prostko EP (2012) Weed control and peanut (Arachis hypogaea L.) response to formulations of imazapic. Crop Prot 36:31-36

Grichar WJ, Nester PR (1997) Nutsedge (Cyperus spp) control in peanut (Arachis hypogaea) with AC263,222 and imazethapyr. Weed Technol 11:714-719

Holm LG, Plucknett DL, Pancho JV, Herberger JP (1977) The World's Worst. Weeds: Distribution and Biology. Honolulu: University Press of Hawaii. 609 pp

Jasieniuk M, Maxwell BD, Anderson RL, Evans JO, Lyon DJ, Miller SD, Morishita DW, Ogg AG, Seefeldt S, Stahlman PT, Northam FE, Westra P, Kebede Z, Wicks GA (1999) Site-to-site and year-to-year variation in Triticum aestivum-Aegilops cylindrica interference relationships. Weed Sci 47:529-537

Johnson WC, Mullinix BG (2003) Yellow nutsedge interface in peanut. Peanut Sci 30:14-18

Mortensen DA, Bastiaans L, Sattin M (2000) The role of ecology in the development of weed management systems: an outlook. Weed Res 40:49-62

[NASS] National Agricultural Statistics Service (2013) Published Estimates Database. NASS-USDA, Washington, DC. https:// www.nass.usda.gov/Surveys/Guide_to_NASS_Surveys/Chemical_ Use. Accessed May 102016

Newsom LJ, Shaw DR, Hubbard TF (1993) Absorption, translocation, and metablism of AC 263,222 in peanut, soybean, and selected weeds. Weed Sci 41:523-527

Richburg JS, Wilcut JW, Culbreath AK, Kvien CK (1995) Response of eight peanut cultivars to AC 263,222. Peanut Sci 22:76-80

Richburg JS, Wilcut JW, Wehtje GR (1994) Toxicity of AC 263,222 to purple and yellow nutsedge. Weed Sci 42:398-402

Ritz C, Pipper CB, Streibig JC (2013) Analysis of germination data from agricultural experiments. Europ J Agron 45:1-6

SAS Institute (2012) SAS/STAT® 9.2 User's Guide. Cary, NC: World Headquarters SAS Institute

Seefeldt SS, Jensen JE, Fuerst EP (1995) Log-logistic analysis of herbicide dose-response relationships. Weed Technol 9:218-227

Senseman SA (2007) Herbicide Handbook. 9th edn. Lawrence, KS: Weed Science Society of America. 458 p

Stoller EW, Sweet RD (1987) Biology and life cycle of purple and yellow nutsedges. Weed Technol 1:66-73

Teuton TC, Main CL, MacDonald GR, Ducar J, Brecke BJ (2004) Green peanut tolerance to preemergence and postemergence herbicides. Weed Technol 18:719-722

Wallace RD, Grey TL, Webster TM, Vencill WK (2013) Increased purple nutsedge tuber sprouting with diurnally fluctuating temperatures. Weed Sci 61:126-130 
Warren LS, Coble HD (1999) Managing purple nutsedge populations utilizing herbicide strategies and crop rotation sequences. Weed Technol 13:494-503

Webster TM (2005a) Mulch type affects growth and tuber production of yellow nutsedge and purple nutsedge. Weed Sci 53:834-838

Webster TM (2005b) Patch expansion of purple nutsedge and yellow nutsedge with and without polyethylene mulch. Weed Sci 53:839-845

Webster TM, Grey TL (2014) Halosulfuron reduced purple nutsedge tuber production and viability. Weed Sci 62:637-646

Webster TM, Grey TL, Davis JW, Culpepper AS (2008) Glyphosate hinders purple nutsedge and yellow nutsedge tuber production. Weed Sci 56:735-742

Webster TM, Nichols RL (2012) Changes in the prevalence of weed species in the major agronomic crops of the southern United States: $1994 / 1995$ to $2008 / 2009$. Weed Sci 60: $145-157$
Webster TM, Wilcut JW, Coble HD (1997) Influence of AC 263,222 rate and application method on weed management in peanut (Arachis hypogaea). Weed Technol 11:520-526

Wehtje GR, Brecke BJ (2004) Peanut weed control with and without acetolactate synthase-inhibiting herbicides. Peanut Sci 31:113-119

Whitaker TB, Slate AB, Giesbrecht FG (2008) Designing sampling plans to detect foreign material in bulk lots of shelled peanut. Peanut Sci 35:159-164

Wilcut JW, Richburg JS, Wiley GL, Walls FR (1996) Postemergence AC 263,222 systems for weed control in peanut (Arachis hypogaea). Weed Sci 44:615-621

Received May 13, 2016, and approved August 16, 2016.

Associate Editor for this paper: Ramon G. Leon, University of Florida 